\title{
IBN-BATTUTA, TRAVEL GEOGRAPHY, KARST AND THE SACRED UNDERGROUND
}

\author{
Ibn-Battuta, geografia de viagens, carste e subterrâneos sagrados
}

\author{
Luiz Eduardo Panisset Travassos * \\ Oswaldo Bueno Amorim Filho **
}

\begin{abstract}
Resumo
O presente estudo procura abordar, com um novo olhar, as contribuições de Ibn Battuta ao desenvolvimento de alguns domínios da geografia, em especial o uso antrópico do carste, bem como o uso cultural das cavernas. Destaca-se que muito provavelmente, os geógrafos do Islã medieval, em suas vertentes sistemática e corográfica, foram uma espécie de "ponte" que faltava na evolução do pensamento geográfico entre os gregos da Antiguidade e os precursores das grandes escolas clássicas europeias nos séculos XIX e XX. Assim sendo, o artigo apresenta uma abordagem alternativa da obra de Ibn-Battuta não só para o estudo da literatura de viagens, mas também, para a Carstologia.
\end{abstract}

Palavras-chaves:Geografia de viagens; Ibn Battuta; Cavernas Sagradas; Carste.

\begin{abstract}
This study is intended to address, under a new approach, the contributions of Ibn-Battuta to the development of certain areas of geography, especially the anthropogenic use of karst as well as the cultural use of caves. Noteworthy to mention is that, most likely, the geographers from medieval Islam were a kind of missing "bridge" in the evolution of geographical thought among the ancient Greeks and the precursors of the great European classical schools in the nineteenth and twentieth centuries. Thus, this article presents an alternative approach to the work of Ibn-Battuta not only for the study of travel literature but also to the study of karstology.

Key words: Travel Geography; Ibn Battuta; Sacred Caves; Karst.

\section{Résumé}

L'étude cherche à entamer, avec un regard nouveau, les contributions d' Ibn Battuta au développement de certains domaines de la géographie, en particulier l'usage anthropique du karst, de même que l'usage culturel des cavernes. Il faut remarquer que, probablement, les géographes de l'Islam médiéval, dans leurs orientations systématique et chorographique, ont été le pont qui manquait dans l'évolution de la pensée géographique entre les Grecs de l'Antiquité et les précurseurs des grandes écoles classiques européennes des dix-neuvième et vingtième siècles. L'article présente une approche alternative de l'ouvre d' Ibn Battuta nou seuhement en ce qui concerne la littérature de voyage mais, aussi, la karstologie.
\end{abstract}

Mots-Clés: Géographie du voyage; Ibn Battuta; Grottes sacrées, Karst.

(*) Lecturer, Doctor of the Pontifícia Universidade Católica de Minas Gerais - Av. Itaú 505, Prédio Emaús, Dom Cabral, CEP: 30535012, Belo Horizonte (MG), Brasil. Tel: (+55 31) 34136370 - luizepanisset@gmail.com

(**) Lecturer, Doctor of the Pontifícia Universidade Católica de Minas Gerais - Av. Itaú 505, Prédio Emaús, Dom Cabral, CEP: 30535012, Belo Horizonte (MG), Brasil. Tel: (+55 31) 34136370 - infoespa@pucminas.br 


\section{INTRODUCTION}

Until a few decades ago it was common to find texts that referred to the Middle Ages as a time of "darkness" for Science in general, and Geography in particular, especially in Europe. A number of academic researchers, which includes those in Western countries, have shown - with increasing intensity - that this does not apply to the medieval Islamic world.

Geography historians, such as Claval (1995), Martin (2005) and Holt-Jensen (2009), or researchers in other fields of study, such as Lyons (2011) or Bissio (2008; 2010; 2012) in Brazil, agree that the teachings of the ancients (especially the Greeks and Indians) were preserved in libraries and Islamic schools in Spain, North Africa, the Middle East, Central Asia, Persia and India after carefully assembled by wise travellers, religious men and even simple amateur travellers.

In the Arab-Muslim Geography development context, Travassos (2013) highlights the names of al-Muqaddasi (945-988), al-Idrisi (1099-1180), Ibn Battuta (1304-1368) and Ibn Khaldun (1331-1406) as some of the ones who were responsible for the emergence of a rich and detailed regional descriptive Geography. Scholten (1980), cited by Holt-Jensen (2009), states, for example, that al-Muqaddasi was the first to adopt fieldwork practice, since his predecessors used to have their reports and work based only on secondary data. On the other hand, Ahmad (1995) points out that Arab-Muslim Geography was strengthened by Al-Ma'mum (813-833) who established the first Academic School of Geography, called the "House of Wisdom" (Bayt al-Hikama). For Gilliot (2006), the libraries - called "treasure of books" (khizanat al-kutub) or "abode of the books" (dar al-kutub) - were part of academic institution. Therefore, they were important to disseminate knowledge among scholars, even though they did not function as the public libraries in the present time.

In the case of Geography, not only the available major works of the ancient Greeks were translated and studied since then, but also major themes and research developed in the classical geography of Greece and Rome were approaches also disseminated. One example of this is Tolmacheva (2006a), who points out that the mapping system developed by the geographer al-Idrisi used a Ptolemaic base that had been assimilated by the early Muslim scholars. The Earth was divided into quadrants and only the inhabited places were described. The types of climate, for instance, were numbered from the south to the north and from the east to the west sections, showing the influence of the Greeks once more. It is important to mention, however, that one should not assign the great advances of Geography in the medieval Islamic world only to this process of assimilation of the Greco-Roman contributions.

At least two factors which are linked to the Muslim religion were among the direct or the indirect causes of the remarkable progress of the geographical activity in the territories of Islam. On one hand, the practical need to have reports and geographical maps of the conquered territories made so that they could be better managed and to facilitate military actions as well. Muslim cartographers produced a pioneer Atlas that recorded routes and kingdoms, which lead to an extremely popular cartographic tradition in Islam. Studies of "political geography" as well as "military geography" - even though such names were not used then, for only later these nomenclatures were created - certainly multiplied within the political-administrative circles and the Islamic military sectors. On the other hand, the oldest, and possibly the most widespread factor for this geographical development in Islam, is linked to the principle of the sacred journey to Mecca. As it is well known, each Muslim must follow this precept. There is a recommendation of the Prophet himself that the Muslim traveller should not hesitate to "get to China", if required to pursuit knowledge and wisdom. Thus, the last-mentioned causes, both of which with religious background, are the ones that have been assumed by the greatest traveller-geographer of Medieval Islam, Ibn Battuta.

According to Waines (2010), Ibn Battuta's book was orally passed on to Muhammad Ibn Juzayy around the year 1356. The complete work - published in 4 volumes in the French edition, which was translated from Arabic in 1854 - can be divided into two main large parts: 1) departure from Tangier towards Mecca; and 2) the Middle East and Asia. Another publication was released in one 
volume in 1993 and is available in Spanish. This one was also used here by the authors.

According to Travassos (2013), with the exception of the works of Bissio (2008; 2010; 2012), the work of Ibn Battuta is not well studied in Brazil yet. In the geographical circles, it is of special interest to the fields of Cultural Geography and Geography of Religion. This is mainly due to the motivation that led the Arab geographer to start his journey: the hajj towards Mecca. Bissio (2010) states that the journey was a religious expression and, at the same time, a way of building knowledge; therefore, a method of study.

In this context, it is believed that it is clear that very little has been made to this date regarding Battuta's contributions to identify subterranean sacred places, no matter whether they are natural or artificial caves. As a result, it is the general objective of this paper to identify how Ibn Battuta records the use of such spaces in the lands he visited, in addition to identifying the existing karst landscape.

References found in Battuta's texts record the human use of underground natural and artificial caves from known Christian holy sites to other less known sites related to the Islam and other religions. One can say that, along the Rihla of Battuta, there are many records regarding the usage of karst landscape elements, especially caves and water sources, as identified by Travassos (2013).

Even though Fanjul and Arbós (1993) highlight some problems in the chronology and the itineraries of Ibn Battuta's journey, its merit as one of the major travelogues of the Islamic World, and also of other areas, is undeniable.

\section{THE ARAB-MUSLIM MEDIEVAL GEOGRAPHY AS THE MAIN AXIS OF THE GREEK CLASSICAL GEOGRAPHY CONTINUATION}

Scholars of the Muslim religion claim that rising in the seventh century of our era happened in quite difficult natural and human conditions. This religion, which continues to spread in all regions of the world, was born and began to expand in the western portion of the extensive Arabian Peninsula, whose natural conditions are described by Burlot (1990, p.13) as "a true sub-continent surrounded by sea on three sides and cut from the West Asian world by the desert". It is also possible to observe that this peninsula is divided by north-south oriented zones: the Tihama (a low coastal plain that stretches along the Red Sea); the Hejaz or "barrier" (an authentic wall, with peaks that surpass two thousand meters); and the Nejd (a large plateau inclined to the Persian Gulf and sometimes covered with huge sand dunes, such as the Nefud and Rubal Khali, "the empty quadrant", one of the most terrible deserts in the world). To the south, the mountains of Yemen and Hadramaut close the peninsula.

In these openly hostile geographical conditions, the population was mostly distributed with low density, concentrated in a few oases and towns scattered along the routes and ports that allowed some trade. Regarding the general characteristics of the populations in this region, the referenced authors are unanimous in considering the Arabian Peninsula as a space of arid, rugged and inhospitable geography (especially the area between Mecca and Medina and the regional surroundings of these two urban centres). According to Bissio (2012), the Islamic identity emerges in a hostile physical environment, more precisely in the city of Mecca, Saudi Arabia, incorporating two vast desert regions: the Persian desert, in the East, and the Sahara, in the West).

From that hostile geographic setting, people dispersed into families, clans and tribes that would take part in two extraordinary developments. In military, religious and political terms, these people were able to extend the Islamic power to the valley of the Indus, on the eastern side, and even to North Africa and the Iberian Peninsula, on the west side. This great achievement lead H.G. Wells $(1920 / 2011)$ - one of the most important British intellectuals of the late nineteenth century and the early twentieth century - to assert tha,t after the death of Mohammed, Abu Bakr became his successor who was dedicated to organize the subjugation of the entire world in the name of Allah. 
Some current French scholars interested in the history of geography have no doubt there is a connection between the development of medieval Arab-Muslim geography and the translation of Greek geographical texts in the Caliphate of Baghdad. Claval (1995) establishes this connection to point out that, just as many other nomadic people, the Arabs had an impressive tradition in the fields of space observation, knowledge about places and geographic orientation, although it was essentially oral and ignored science and philosophy. It was only after The Conquest that they started to dominate the Byzantine and Syrian urban elites in the Near and Middle East and discovered the richness of the Greek thought. "The translations of these works began to multiply in Baghdad, Iraq, under the Abbasid Caliphate in the eighth and ninth centuries. The Arab geography truly blooms from 800 to 1050; the use of Arabic is then widespread, even among the authors originating from Persia or Central Asia" (CLAVAL, 1995, p.20-21).

Emmanuelle T. du Mesnil, a historian from the University of Paris Ouest, is positive about this connection and says that the Arab geography is the "daughter of the Caliphate of Baghdad", and so it is true that the rediscovery of this ancient science is closely linked to the existence of the Caliphate (DU MESNIL, 2010, p.15).

The geography of the ancient Greeks and the early Roman Empire, from Homer to Ptolemy, is of course varied and complex, featuring a real epistemological breakout with everything that had been done so far in this field of knowledge. Nevertheless, among the Greeks themselves, there were those who could epistemologically synthesize the various aspects of geography in just a few branches or categories. In one of Strabo's few geographical works that are still complete nowadays, he divides this knowledge into two major complementary sub-disciplines: general geography and special geography.

The classic typology of Strabo would eventually become a key reference and famous geographers of several generations (even those from recent times and the present days), who took it again with only slight modifications. Thus, the general geography of Strabo was also called systematic geography, while the specialized geography became also known as chorography or - after the first half of the twentieth century - regional geography (CLAVAL, 1995; DU MESNIL, 2010). Among the main geographers who accepted the logics of the division of geography originally proposed by Strabo one can mention the Germans Varenius, Kant, Ritter, von Richthofen and Hettner (among others), the French Baulig, Clozier, Cribier, Drain, Durand-Dastès, Meynier and George, as well as the North American Hartshorne.

It is possible to say that the Arab-Muslim geographers are as numerous as the geographers of ancient Greece. If their works are analysed from an epistemological point of view, it will be found that, except for the role played by religion in the geography of the first, both Arab-Muslims and Greeks explored themes and had very similar contents, even though that happened in different places and some centuries apart. Measurements of the surface of the Earth, world maps, globes and geomorphological and climatic processes were subjects of the general geography of the Arab-Muslim geographers as well as among their Greek counterparts just to name a few items. In the axis of chorological (or regional) geography, Muslim travelers described features of physical geography in their journeys, which were often far more extensive than those of the ancient Greeks, routes and its surroundings. They recorded details related to the cities, such as economics, equipment, and the customs of inhabitants and also made a large register of places, buildings and monuments with religious functions.

\section{THE RIHLA OF BATTUTA}

The Rihla of Battuta is one of the greatest examples of "travel literature", not only back in the Middle Ages but also in the entire history of literature. It is also a milestone in the literature of Islam and a historical and geographical document which is essential to understanding a great part of the medieval world. 
Among the Muslims, the Rihla presents itself as one of the four main types of displacements or travels, carried out by them and encouraged by Islam. According to Methal R. Mohammed (2011), Islam encourages mobility as religious and social practices that happen in four main ways: 1) the hijra (migration), travel to non-Muslim lands (dar al-Kufr) and to Muslim lands (dar al-Islam); 2) the hajj, the pilgrimage to Mecca, which is one of the five pillars of Islam; 3) the ziyarat, a visit to holy places, and; 4) the al-Rihla, the journey in search of knowledge. Reading texts written by the medieval Arab-Muslim pioneers of geography, one can see that some of them combined two or more forms of travel, such as the hajj and the al-Rihla.

Putting hierarchies and typologies aside, it is necessary to highlight the function of a journey in the medieval Islamic world. This role, largely ignored by much of the Western intellectuals for centuries, was fundamental to the consolidation of the central position of the Muslim civilization in the cultural life of the Middle Ages between the eightieth and fourteenth centuries. Regarding this fact, the words of Bissio (2012) are some of the clearest ones written in Portuguese. He stated that, throughout the Middle Ages period, the journeys were part of the lives of scholars of the Islamic world for they wished to perform pilgrimages to the holy places and to seek recognition as literate men. These required displacements, whose extension in space and time could consume a significant part of their life. Traveling around Muslim areas and meeting great masters served to improve their knowledge, a pre-requisite for joining the select "stronghold of the wise, the doctors, those who were the glory of Islam in the revered land of knowledge. The journey was a religious expression and at the same time, a form of construction of knowledge" (BISSIO, 2012, p. 145).

Although this type of journey had been practiced for religious purposes since the early days of Islam, in the seventh century, they only became thematic or even a literary subgenre in the tenth century. According to Bissio (2012, p.170), "in mid-tenth century begins to emerge the journey within the Muslim areas such as literary theme, with concrete and personal descriptions of Islamic domains". For the author, it is curious that travel reports only appeared when multiple poles of power within Muslim territories replaced the Caliphate unit, re-shaping the political and administrative geography of the land. From then on, the narratives began to favour travel experiences within the Islamic space that was still occupying most of the known world even though it was politically divided. Its cultural boundaries separated the Umma (Nation) from the rest of the world, which was dominated by the infidels. Such voyages were those made eternal through their own written characteristics and gave birth to the literary genre known as Rihla.

Thus, the Rihla of Battuta, written in the fourteenth century, which is probably the best known journey among those produced by the great medieval Muslim travellers, is far from being the first one chronologically speaking. Battuta was inspired and benefited from the information contained in previous rihlas, especially one of them: the one of Ibn Jubayr. So, in relation to the work of Battuta, the pioneer Rihla of Ibn Jubayr is a model to be followed and, if possible, overcome. Moreover, it was an invaluable source of data and descriptions of places and cities that would be visited by Battuta over a century later.

In one of her recent papers, Kathleen Bush-Joseph, a North American historian, describes the contributions of the Andalusian traveller and writer Ibn Jubayr (1145-1217) to the development of the Rihla literary genre and the work of Battuta. The author states that one of the main reasons for Ibn Jubayr to be still studied to date is the fact that he played an important role to inspire and influence a whole Arabic literary genre. Bush-Joseph (2012-2013, p.12) states that although the author was not the first Andalusian to venture on a pilgrimage, Ibn Jubayr was one of the first to diligently record the details of his journey and make it circulate among a relatively simple audience (...) thus ensuring a place in history. Since, in Arabic, the word Rihla means a trip or conference about a trip, Ibn Julayr is considered a precursor and Ibn Battuta is his "successor" in this genre (BUSH-JOSEPH, 2012-2013). 
Ibn Battuta was born to a Muslim family of Berber origin, in the city of Tangier, Morocco, in 1304. In 1325, he began a journey whose initial goal was to go on a pilgrimage to the sacred Mecca where, in fact, he arrived after traveling for a year. Instead of returning immediately to his city, Battuta began another extraordinary journey in search of knowledge and that led him to the main centers of Islam at that time and even to the borders of the Islamic world in Asia (India and China) and Africa (Mali). His definitive return to Morocco only occurred in 1352-1353, when he dictated his travel memoirs to Ibn Juzayy, the writer who made Battuta's Rihla (Figure 1) famous, a book with over 1,000 pages in three volumes in one of its latest version: the translation of Defremery and Sanguinetti, published in Paris in 1997. Moreover, since the first full translation of Defremery and Sanguinetti, in the mid-nineteenth century, the Rihla of Battuta has been the subject of numerous analyses and descriptions in recent decades, as mentioned before.

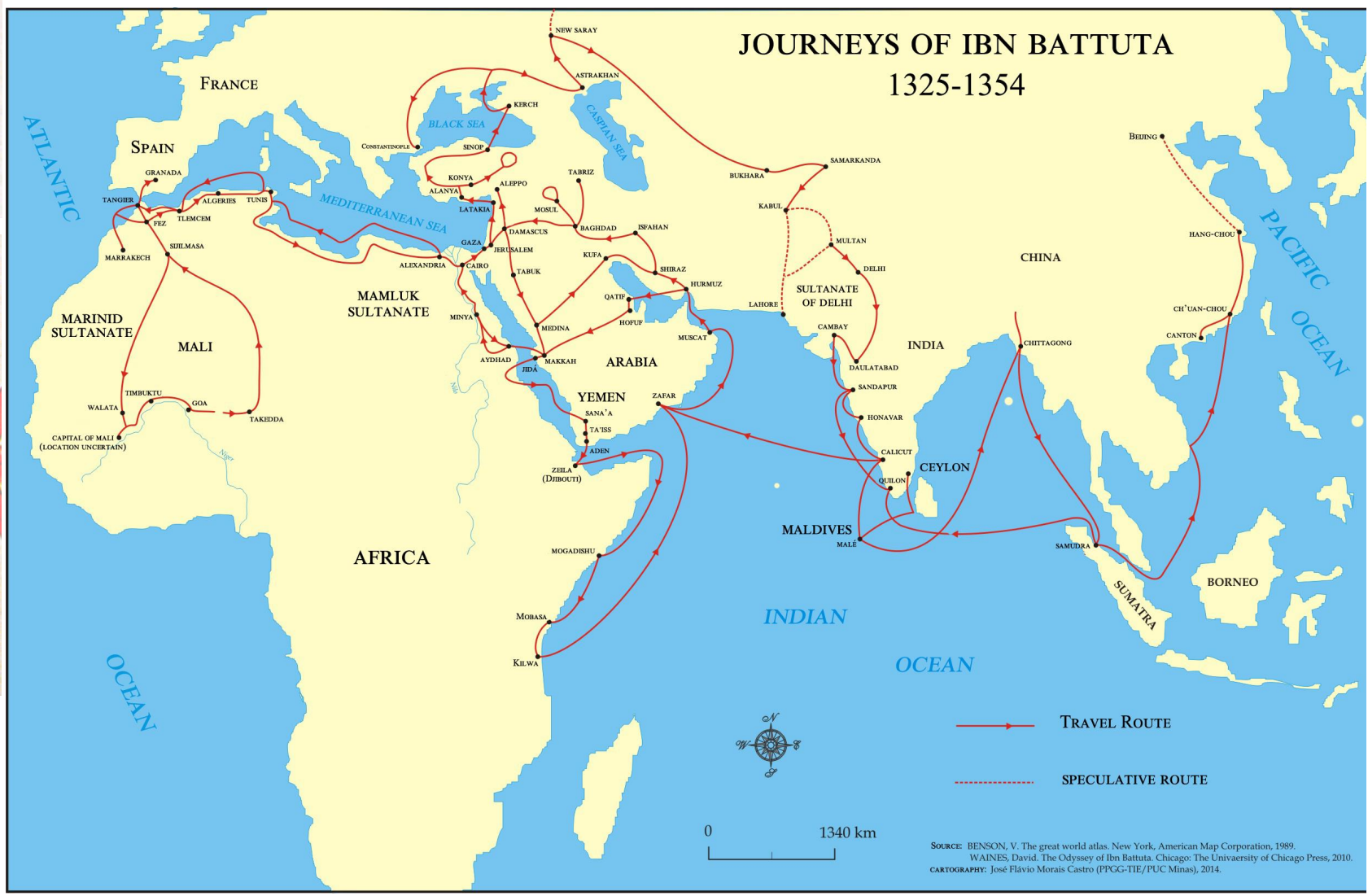

Figure 1 - The travels of Ibn Battuta

Source: WAINES, 2010, p. XII-XIII; Cartography: Prof. Dr. José Flávio Morais Castro.

On a careful reading of Battuta's Rihla, the main and recurring themes of this travel report can be identified. Amongst the various aspects described by Battuta, the ones that are linked to the theme of this article are those related to physical geography, pilgrimages, holy men, thinkers and religious leaders.

\section{THE SACRED UNDERGROUND OF ISLAM}

According to Gaarder, Hellern and Notaker (2005, p.18), humans began to realize nature and its forms as animated since its establishment. Then, a period of evolution started when humans came to believe that animals, rivers, mountains, trees and caves, for example, contained spirits. In relation to this type of use of the underground by Muslims, Andreychouk, Travassos and Barbosa (2010) state that for many of the practitioners, worshiping a particular landscape seemed to be unacceptable.

Although the worship of a natural feature is not broadly accepted as part of Islam, it is possible to find, in the literature, some examples of caves that are perceived by Muslims as sacred places. 
The best known of all is the Cave of Hira, which is considered sacred because it was there that Prophet Muhammad received divine revelations (Figure 2).

Even without a detailed study of the Qur'an, it is possible to identify one more sacred cave that was part of the story of the founder of Islam. The Savr Cave, also in Mecca, would have been the place where Mohammed and his friend Abu Bakr were hidden for three days as recorded in the 9th Surah, verse 40: “(...) when they were in the cave and he said to his companion, 'Do not grieve; indeed Allah is with us!'(...)".

It is important to notice that the 18th Surah of the Qur'an is called The Cave (AL-KAHF). Full of symbolisms, this section depicts the cave as a safe place where a group of youngsters took refuge and says, "Lord, grant us Your mercy and prepare for us from our affair right guidance!" (Qur'an 18:10). In the same chapter, the youngsters would have "fallen asleep in the cave for years" (Qur'an 18:11) and "they remained in their cave for three hundred years and nine" (Qur'an 18:25).
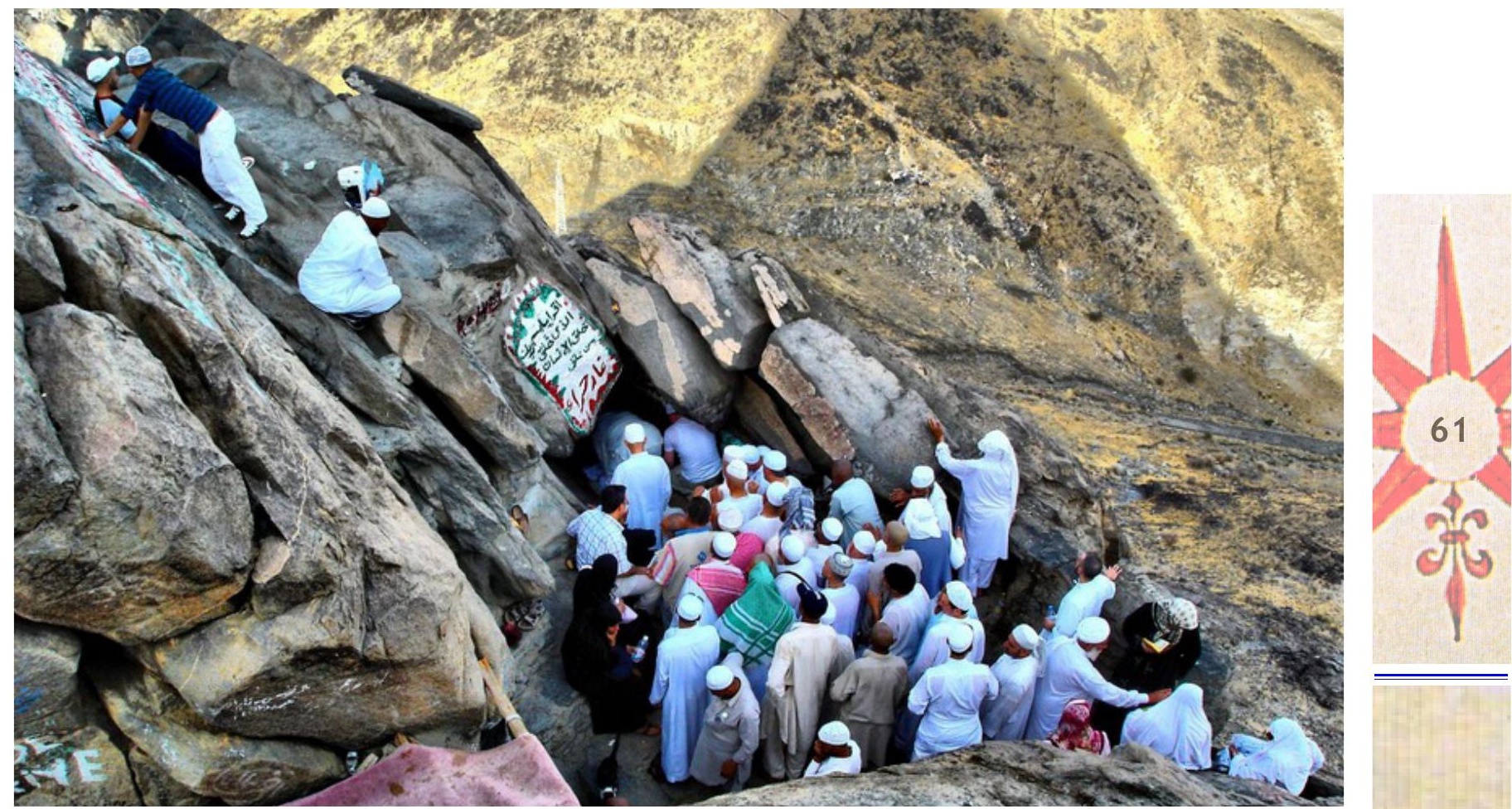

Figure 2 - Muslim peregrines gathering and entering de Hira Cave, in Mount Hira, Mecca (Photo: Nacizane, 2008) Available at: <http://commons.wikimedia.org/wiki/File:Hira_ma $\%$ C4\%9Faras\%C4\%B1.jpg>

For the study of sacred places, it is interesting to observe the similarity of this Surah with the legend of the Cave of the Seven Sleepers in the Christian belief. Located in Ephesus, Turkey, it would be the place where, according to this legend, youngsters have sought shelter during the persecutions in the Decius period (250 A.D.). There, they would have fallen asleep and, miraculously, awake in the year 435, in the times of Theodosius II (TRAVASSOS, 2010).

However, except for these sacred caves, many others are not located in North Africa nor in the Near and Middle Easts. Many are worshiped by certain social groups in countries where the Muslim religion does not prevail and the journey to the places of worship is characterized as a pilgrimage full of sacrifice and dangers. Andreychouk, Travassos and Barbosa (2010) point out that many of these sacred underground spaces are located in regions where the Islam did not exist. Therefore, they were considered sacred prior to that religion. Over the years and with the growth of the Muslim religion, local groups knew about such spaces mainly through oral tradition narration. Several other examples can be found in Bosnia and Herzegovina, Tajikistan (Cave Chodza Ischak), in Crimea (Cave of the Forty Saints-Kyrk-Aziz), and Indonesia (Cave Cerme), for instance. 
Like his predecessors and travelers of his time, by undertaking a journey of that nature Battuta accepted the risks as part of the sacrifice for acquiring new knowledge. Throughout his journey, the karst landscape was present and some records about it were made. In spite of not being considered as "karstological" records, they deserve to be highlighted since they show a perceived relationship between humankind and this type of landscape.

\section{THE KARST AND THE SACRED UNDERGROUND IN IBN BATTUTA'S TRAVEL}

Although there are no specific parts regarding the karst or carbonate reliefs, one can identify the description, in his work, of phenomena that occur more commonly in karst landscapes (e.g.: caves and underground water sources). Although the African continent presents little karst, if its territorial extension is taken into account, significant examples of this type of relief are found in the northern area. So, it can be said that many of the places that Ibn Battuta went through on his journey to Mecca are known carbonatic regions in the northern region of the continent. In the first 10 months of travel, areas of Morocco, Algeria, Tunisia, Libya and Egypt were visited. Although only a few pages have been dedicated to these first four countries, it is worth pointing out some general aspects of the regional karst.

In order to prove this, Perritaz (2004) states that Algeria has the largest and deepest cave systems in Africa: the Boll Maza, with $18.6 \mathrm{~km}$, the Anou Ifflis (-1170 m) and the Anou Boussouil (-805 $\mathrm{m})$. The author points out that for many years Morocco was ahead of this ranking. Near Tangier, Battuta's hometown, there is a tourist cave (Cave of Hercules). Oldham (2004), cited by Duckeck (2011), assets that it is the best known tourist cave in Tangier. It is important now; however, the cave was discovered only in 1878 and, of course, it does not appear in the works of the Arab geographer.

During his first voyage (1325-1326), on leaving Tangier towards Mecca, Battuta traveled along the Mediterranean coast in the terrains of the Moroccan Rif (Er Riff). Even though there are no continuous carbonates, there are some important places there. Perritaz (2004) claims that less than 1,000 caves have been discovered there but the country has more than $100,000 \mathrm{~km} 2$ of karst terrain.

The Paleozoic limestone is found in the Anti-Atlas domain where they are more than 300 meters thick and become thinner towards the sea. Exokarst features are more common than caves. In the Atlas mountain range there are important underground aquifers that are sources of the main Moroccan rivers. Jurassic limestone is common in the High and Middle domains of the Atlas Mountains and the east side of the country, comprising about $20,000 \mathrm{~km} 2$. Therefore, almost the entire territory of Morocco presents karst springs. In the plains of Morocco, natural openings in the rock formations allow natives to dig and store "cereals and other provisions", as it was pointed out by Reclus (1876-1894, p.353).

In Algeria, Battuta highlights the capital, Algiers, without mentioning its karst or karst features. However, based on cartographic documents and literature, it can be said that Algerian caves have been used as shelters and sanctuaries throughout history. The evidence of human occupation is pointed out by Collignon (1997), cited by Perritaz (2004), who stresses the presence of cave paintings in the rock shelters of Tasslli N'Ajjer, in the southern portion of the country. Even today, one can see shepherds who use the underground as their shelters. Another interesting aspect of the historical use of Algerian caves is the fact that many of them were used as shelters, bunkers and small field hospitals, from 1954 to 1962, during the war for independence. It is noteworthy that Romans, Vandals, Byzantines and Arabs occupied that area in the seventh century, when the Arabs began the native population Islamization process, until the sixteenth century, before the Ottomans extended their power to that region. From 1830 to 1962, France managed Algeria as a colony and reports regarding the use of caves by the local population, as well as by the country's liberation forces against the colonizer, were common.

Elisée Reclus (1876-1894) recorded such uses when writing about Mazuna, the birthplace of Mohammed Ben Ali-es-Senûsi, founder of the powerful order that preached everywhere about the 
return of the pure teachings of Islam and hatred towards Turks and Christians. The author states that on the heights of Nekmaria, further to the west, there is a fort and that below this fort it is possible to find a cave of sad memories, where General Pelissier caused the death of the Uled-Eiah tribe smothering them with smoke in 1845, (RECLUS, 1876-1894, p.282).

Along the probable route of Battuta, there are small carbonate mountains to the north and Perritaz (2004) mentions four provinces or major karst units: 1) the Oran Meseta Plateau; 2) Tell Mountains; 3) the Constantine tabular massive, and 4) the salt and gypsum diapers. From these four units, the Oran Meseta Plateau emerges as the largest Algerian karst plateau with 6,000 km2 and Jurassic limestone and dolomites at 800 to 1,500 meters. In this region, large underground rivers and the main karstic plains of the country are common. The underground rivers are the main sources of water, especially in the dry Algerian summer. Traditional karst forms (e.g.: karren, dolines and shafts) are found in the Tell Mountains and are mainly carved in Jurassic and Eocene limestones. In the Constantine region, thick Cretaceous limestone $(300 \mathrm{~m})$ has numerous dolines and shafts in an area of 18,000 km2. Further north, the fourth unit has Jurassic limestone that overlaps Triassic sequences with abundant layers of salt and gypsum. Schlüter (2008) points out that many of the existing aquifers are already polluted, confirming the fragility of groundwater due to anthropogenic actions.

From Algiers, the capital city, Ibn Battuta went towards Tunisia, a country with extensive shallow and little karstified carbonate regions as well. However, the country also has extensive underground systems such as those cited by Perritaz (2004). One can identify the Rhar Ain et Tsab (2,700 $\mathrm{m}$ long and $160 \mathrm{~m}$ deep) and the Rhar Djebel Serdj (1,700 $\mathrm{m}$ long by $267 \mathrm{~m}$ deep). Thermal karst sources exist in this territory and some ancient Roman cisterns (Figure 3) were built in abundance as demonstrated by Travassos (2010). Such anthropogenic structures are extremely valuable and make the strategic value of karst landscape quite clear, particularly in relation to water availability since the "the cisterns, more precious than all other structures, have been always either kept up or repaired under every change of Government." (RECLUS, 1876-1894, p.157). In the western portion of Tunisia, south of the city of Sfejerda, Reclus portrays the richness of water sources, "a feature of paramount importance in these arid regions. One of the springs starts up from a cavern decorated with Roman arcades, which can be followed for some distance into the interior of the rock." (RECLUS, 1876-1894, p .180-181).

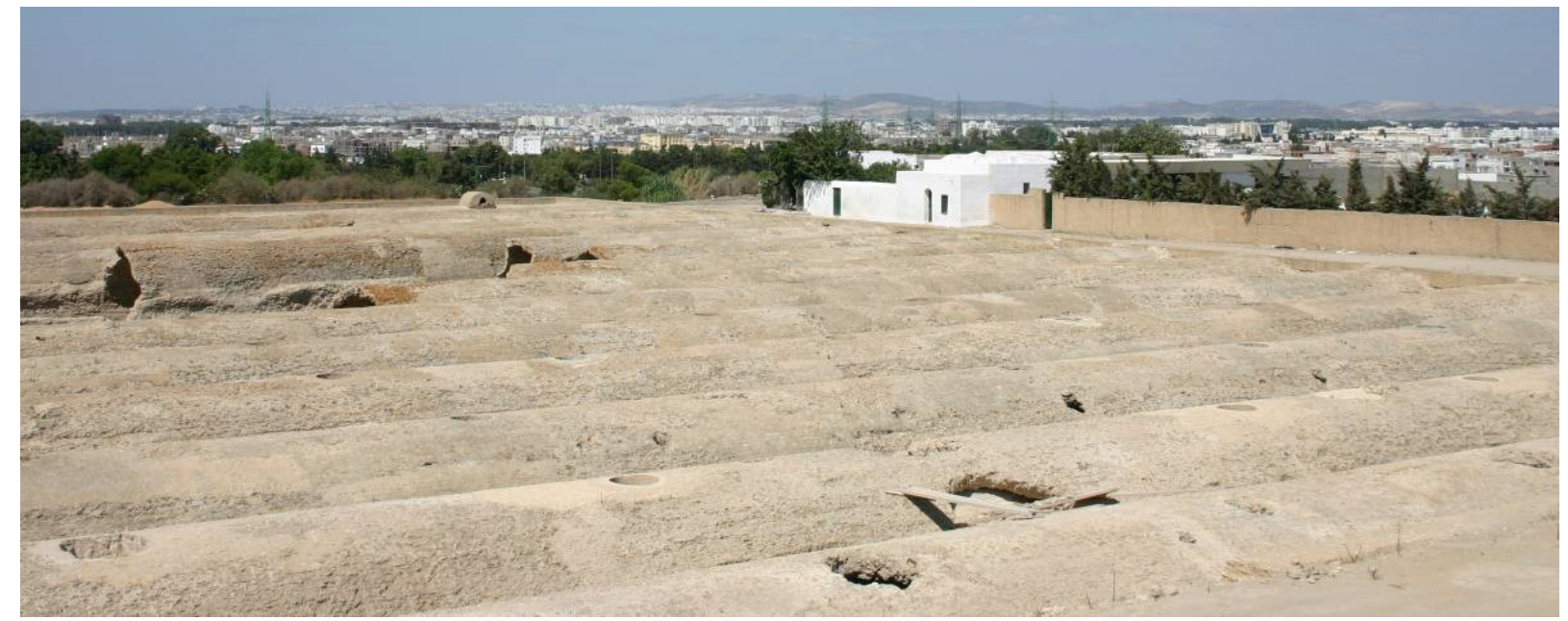

Figure 3 - Partial view above the Roman cisterns, south of Tunis, Tunisia (Photo: L. E. P. Travassos)

In the capital of Tunisia, Tunis, the oldest sacred underground structures are the "sepulchral chambers still to be seen hollowed out of the soft limestone, similar in the internal arrangements of their galleries to the caves used as tombs in Phoenicia and Palestine." (RECLUS, 1876-1894, p.157). The carbonates of Tunisia favored the underground constructions, dwellings of the Berber 
people farther south towards the Sahara. Between Sfax and Gabès, locations which were identified by Battuta, such massifs, excavated by the Berbers for centuries, are located (Figure 4).

Leaving Gabès towards Tripoli, in Libya, Battuta would have passed through a karst that Klimchouk et al. (1996), cited by Perritaz (2004), highlight as one consisting of horizontal Jurassic carbonates approximately $400 \mathrm{~m}$ thick, with gypsum layers intercalated by dolomitic ones. Presently, four tourist caves are identified in the country: Beni Add, Ghardaïa, Hamma, Merveilleuse and Tassili n'Ajjer. Based on Schlüter (2008). One can infer that the route used by the Arab geographer had limestones intercalated with sandstones and marbles.

Although not identified in the work of Battuta, the sacred underground was recorded by Elisée Reclus, an important French geographer of the nineteenth century. The first pages of the 11th Volume of his Universal Geography, dedicated to the African northwest, record the custom of burying the dead in caves. Cyrene, an ancient Greek colony (nowadays, Libya) is full of these "sepulchral caverns seen in thousands, and here and there the traces may still be distinguished of their polychrome decorations (...). Most of the tombs rest on crypts cut in the limestone cliff, which being of a porous nature, was easily worked on, and thus converted into a vast underground city"(RECLUS, 18761894). It is noteworthy that the graves are identified and described in abundance in Battuta's text and maybe some of them were not identified because they were not part of the Muslim tradition.
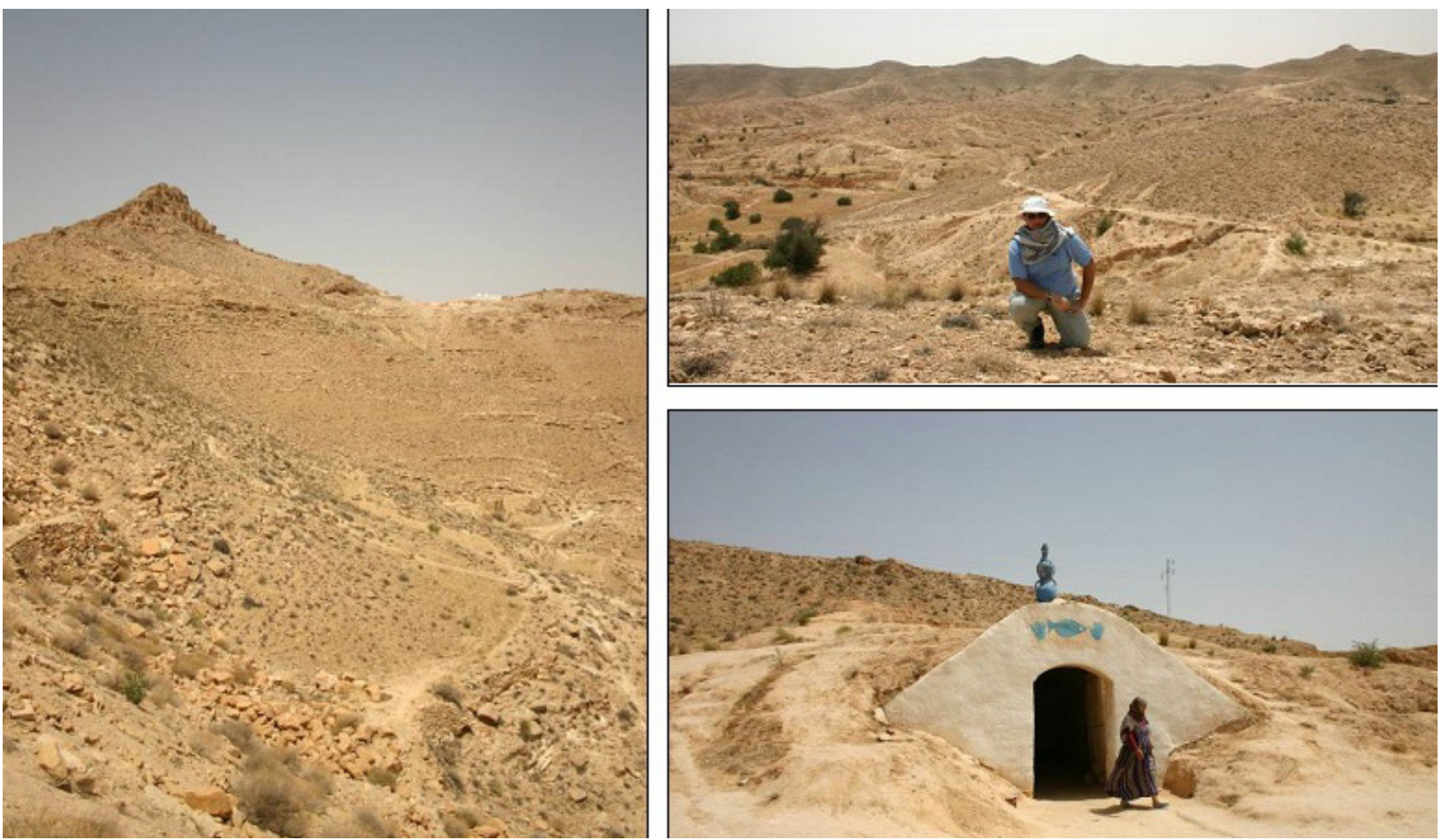

Figure 4 - Region of Matmata, located between Sfax e Gabès, Tunisia (Photo: L.E.P. Travassos)

To get to Egypt, Battuta had to cross the Miocene carbonates of the Western Desert and the Quaternary coastal sediments until he reached the city of Alexandria and, then, Damietta. In this region, the geographer devoted several pages of his Rihla to the description of the people, their customs and geography. About half of the Egyptian territory has carbonate outcrops and, in some cases, gypsum. Perhaps the most famous regional karst plateau is the Plateau of Giza, where the well known pharaonic pyramids are located. Regarding such constructions, Battuta (1356/1993, p.138) stated that they were "built by solid hewn stones, of colossal height, circular, broad at the base, narrow at the summit. Similar to cones, no doors; no one knows how they were built (...)" and were erected with the purpose of being the place for the "burial of the royal corpses"(BATTUTA, 1356/1993, p.138).

Leaving Cairo towards the south to Edfu, and then returning to the capital by the east bank of the Nile, Battuta went through Miocene and Eocene limestones. From Edfu, Battuta traveled to 
where Marsa Alam is today and went through Palaeozoic and Pre-Cambrian land (Figure 5). He returned from this location to Edfu and moved north on the east bank of the Nile to Cairo, passing by the same limestone of the opposite bank. Perritaz (2004) claims that the regional karst presents just a few features. There are karst springs and caves known for providing water and shelter. One can even say that the Monastery of St. Anthony, located to the east of Cairo, only exists because of the caves and water sources that exist there.
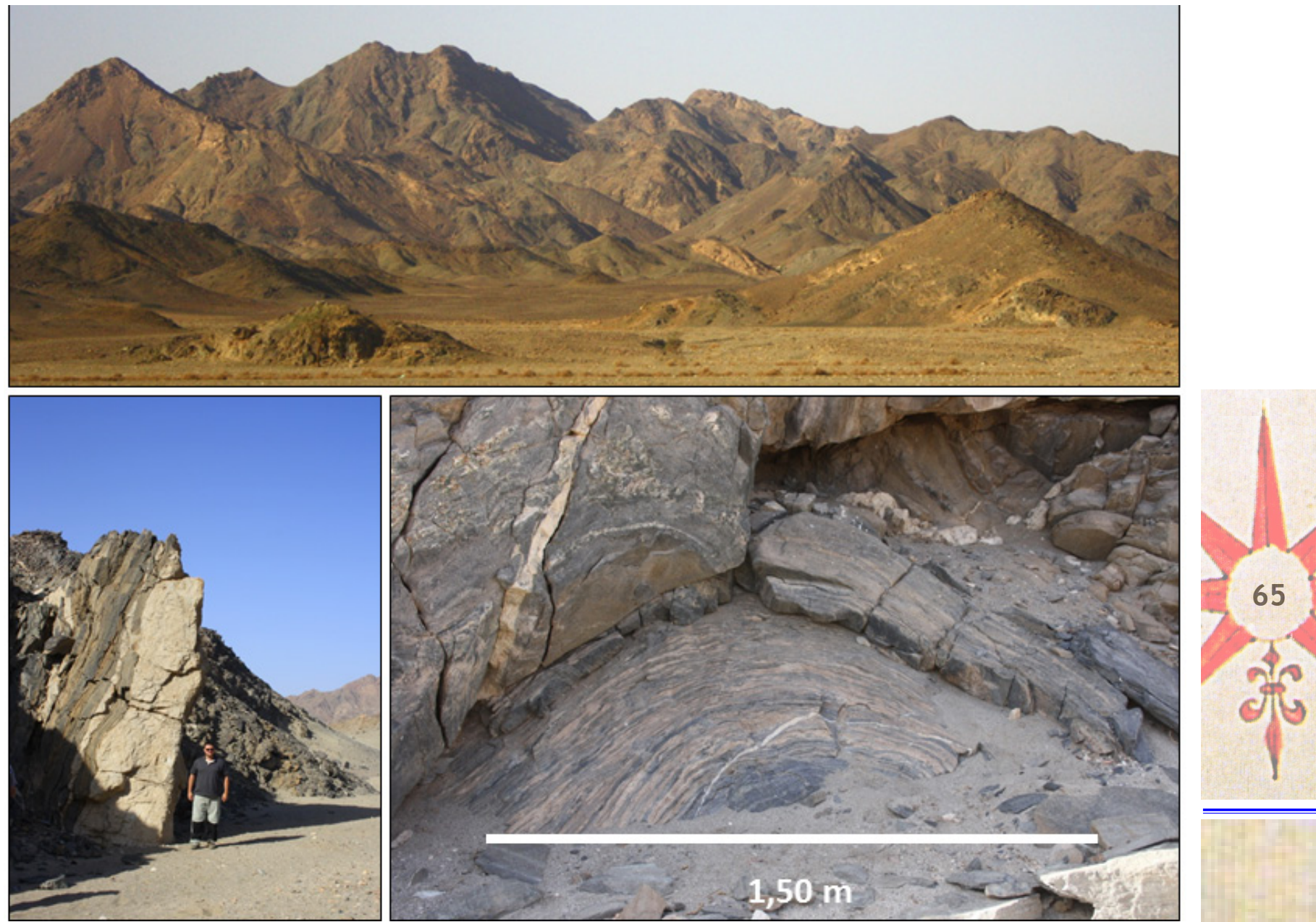

Figure 5 - General aspects of the land in the eastern bank of the Nile. The two images below identify volcanic structures and folds resulting from intense geological activity in the past (Photo: L.E.P. Travassos).

From Cairo, Battuta crosses the Sinai towards Palestine [Israel] and Syria, where records concerning the sacred underground are more frequent. In several points in his work, caves, tombs, sepulchres and some temples perceived as sacred spaces are mentioned. In Gaza, he describes the importance of mineral resources for the construction of temples. In Hebron, he highlights the existence of a temple built under the rule of "Solomon, who ordered (...) its construction. Inside it, it is located the holy and venerable cave, which houses the tombs of Abraham, Isaac and Jacob (...), and their spouses (...). Inside it, there is a passage to the blessed cave (...)" (BATTUTA, 1356/1993, p.150-151), which the Arab geographer claims to have been to in several occasions.

Presently, the Tomb of the Patriarchs, as the site is known, is an architectural complex built around the Cave of Machpelah. It is considered the second holiest site of Judaism. It also has high sacred value to Muslims and Christians, who also revere Abraham as a real prophet of God. Steward (2005) reminds us that, for religious traditions, the cave is considered to be a gateway to the Garden of Eden.

In that region, Battuta visited "the cave where the tomb of Fatima, daughter of Husayn, son of Ali is" (BATTUTA, 1356/1993, p.152), the great-granddaughter of Muhammad, according to 
the note of Fanjul and Arbós (1993). It is important to point out that one should not get take this Fatima for the other Fatima, who was the daughter of Muhammad.

From Hebron, Battuta went to Jerusalem and visited Jonah's mausoleum. In Bethlehem, the geographer highlights the birthplace of Jesus, where "there is a great structure" venerated by Christians to "offer hospitality to those who come". This is the Church of the Nativity, considered one of the holiest sites in Christianity. According to the narratives presented in the texts of the Evangelists Matthew and Luke, it is the traditional site of Christ's birth. According to Travassos (2010), even though the word cave is not mentioned at all in the biblical text, it is reasonable to say that the place was indeed a cave, due to the fact such features are common and are used as stables in that region.

In the Valley of Yahannam [Jahannam, Hannam], Battuta states that "at the bottom of the valley there is a church that Christians very much appreciate, claiming to be the tomb of Mary and other much praised, where pilgrims go and think to be the tomb of Jesus." (BATTUTA, 1356/1993, p.154). Travassos (2010) notes that the site is known as the Church of the Holy Sepulchre, also called by the East Orthodox as the Church of the Resurrection. The place is considered an important pilgrimage center since the fourth century and remains as one of the holiest Christian sites in the world.

Waltam (2004) states that Israel has a karst made of Cretaceous and Tertiary limestone as well as portions of gypsum in the Judean desert. Although not identified by Battuta, Mount Carmel has many caves and, among them, the holy Cave of Elijah. On this site, considered an important temple for Jews, Muslims, Christians and Druze, it is believed that the Prophet has lived and spread his teachings. Important events related to the life of Elijah (ninth century B.C.) would have occurred in this place, including the fact that it is believed that he lived and meditated in this cave before defeating the pagan prophets on the Mount. Tradition also says that the Holy Family (Mary, Joseph and Jesus) would have taken shelter in that cave for a night while returning from Egypt (TRAVASSOS, 2010).

Leaving Jerusalem, Battuta moved towards the north of Syria and then moved south towards Mecca. It is noteworthy that, at that time, the current territory of Lebanon was part of Syria, which is why the geographer made no distinction between them in his narrative. After some pages on which the geographer is not very explicit regarding karst or its features, he emphasizes Mount Aqraa and Mount Lebanon: “(...) I went towards the Aqrac hill, the highest in Syria, and the first that stands out from the sea. It is inhabited by Turkmens and has water sources and streams. From this place I traveled to Mount Lebanon, one of the most fertile in the world (...), there are water sources (...) and there is no lack of hermits, ascetics and devote men to the service of God (...)." (BATTUTA, 1356/1993, p.177). The simplified geological map of Lebanon (WALLEY, 2011) shows that the majority of the territory is developed on carbonates. The Mount Lebanon, specifically, is composed of Cretaceous and Jurassic limestone.

Concerning the regional karst, Waltham (2004a) affirms that, while Syria presents few visible signs of karst features, the underground has one of the largest karst aquifers in the desert Jurassic limestone in the world. Damascus is supplied by the Fijeh karst spring. Tertiary limestone is located in the southeast forming the Chami Plateau. Lebanon is regionally known for having the largest karst region developed in Jurassic limestone west of the Beqa'a Valley. The water of the caves found in this valley appears $18 \mathrm{~km}$ near the sea in Fawar Antelias. Ghannam, Ayoub and Accra (1998), cited by Waltham (2004a), point out the submarine sources of the Mediterranean coast originating from Mesozoic and Tertiary karstic aquifers.

Nowadays, one can see the monasteries of Maalula in Syria, located about $50 \mathrm{~km}$ from Damascus, in the direction of Lebanon. Although not specifically recorded in the work of Battuta, it is reasonable to say that such sanctuaries existed in the region. In the book section dedicated to Syria, there are many records about temples, tombs and sanctuaries. These monasteries are located north of Damascus and the geographer mentioned a sacred cave on Mount Qasiyun [Qasioun], also to the north. It is perceived as a sacred place, because "it is the site where the prophets ascended to heaven. Among the places of pilgrimage is the cave where Abraham was born, the servant of God. 
It is an elongated narrow cave where there is a large mosque (...). From this cave Abraham saw the star, the moon and the sun, according to the Holy Book [Qur'an].'(BATTUTA, 1356/1993, p.194).

To the west of Mount Qasioun, another place of pilgrimage is "the Cave of Blood, on which, on the mountain, one can see the blood of Abel, son of Adam (...) because it is believed to be the place where Cain killed his brother. People ensure that, Abraham, Moses, Jesus, Job and Lot prayed inside it. Also in the vicinity, there is a mosque of perfect construction, which one can go by climbing a ladder (...)."(BATTUTA, 1356/1993, p.195). On this Mount, it is also possible to visit the "Cave of Adam (...) and below it, the Cave of Hunger, in memory of the seventy prophets who took refuge in it and only had a small bread" (BATTUTA, 1356/1993, p.195) to satiate their hunger. The cave where Jesus and his mother would have taken refuge is also venerated in the Qasioun. "The blessed refuge is a small cave in the middle of the hill, like a small abode in front of another one in which was the oratory of Elijah. People are quick to come and pray here. The refuge has an small iron door and is surrounded by the mosque (...) where water that falls from the top is collected (...)." (BATTUTA, 1356/1993, p.195).

Battuta recorded that the Mount is also responsible for the water supply of the city of Damascus, "because there are water sources (...). The waters are divided into seven streams, each with a different direction (...). The biggest one is the Turah, which descends the hill, having dug its bed in the hard rock in the form of a large tunnel." In some part of the river's underground course, it is used by some "courageous swimmers who throw themselves in the water at the top of the hill and are swept away by the current to go underground till the base of the hill (...)." (BATTUTA, 1356/1993, p.196).

From Damascus, Battuta moved to the south towards Mecca, passing initially through the lands that are now part of Jordan, coming to Medina (Saudi Arabia), where he spotted several tombs and sacred tombs. On the pages dedicated to Medina (BATTUTA, 1356/1993, p.207-222), he mentioned "some egregious extramural sanctuaries of the noble Medina." He points out Mount Uhud as another "venerable sanctuary (...) located north of the egregious Medina (...)." From Medina to Mecca, Battuta would have passed the Pre-Cambrian and Tertiary lands where Mount Hira is located.

Many pages were dedicated to describing the Hholy City of Muslims "surrounded by mountains" and its numerous holy sites. For this article, emphasis will be given to the "blessed well of Zamzam" (BATTUTA, 1356/1993, p.223; 230-231), considered as the source of water that had been created by God to quench the thirst of Abraham and his son Ishmael. The importance of this karst feature is confirmed by the existence of a research center, the Zamzam Well Research Center, under the Institute of Geological Survey Arabia. According to this center, water there has been used for at least 4,000 years.

Battuta describes other shrines outside the city limits as well as a section dedicated to "the mountains surrounding Mecca" (BATTUTA, 1356/1993, p.237). The most important is Hira and its sacred cave. "People go to this venerable cave with the intention to enter the same site that was used by the Prophet (...). There are those who pray in front of the cave without entering it. The locals say that those born of legitimate copulation can enter; adultery products cannot. Thus, many are those who try to enter to avoid shame or scandal." (BATTUTA, 1356/1993, p.238).

Starting from Mecca towards the east, the traveler go through the lands of Iraq and Iran. The first has limited karst features in the northwest (Sulevani Plain), especially for being an extension of Miocene carbonate from the Syrian karst plain. In its central part in the lowlands of Mesopotamia, no type of carbonate karst is identified and only a small carbonate range is seen being derived from the limestone of Zagros Mountains in Iran. Waltham (2004a) describes the Mosul area as a place where rivers run through dolines and karst springs arise. In the work of Battuta, records were made concerning tombs excavated in the rock and the existence of water sources. Sacred tombs have been built to "(...) Adam, Noah and cAlī (...)" (BATTUTA, 1356/1993, p.266-267), among others. 
Headed to Baghdad, tombs of "saint sheikhs" and sultans are identified without, however, being specifically natural caves. In the city it is said that there are "eleven mosques in which one can recite the jutba and pray (....): Eight on the west side and three on the east (...)". The karst can be identified by the "many baths" existing in the city and the "sources that exist between Kufa and Basra (...), which arrives in Baghdad.” (BATTUTA, 1356/1993, p.314). In the eastern portion of the city, Battuta identifies a grand sanctuary with the tomb of cAwn, one of the sons of cAlī b. Abu Tâlib in its interior and relates "the tombs of the caliphs of Baghdad and the tombs of some ulama and devout men" (BATTUTA, 1356/1993, p.314-315).

In the region of Mosul, of important archaeological sites today, Battuta (1356/1993, p.324) points out that "it is ancient and with fertile soil" presenting many mosques and baths. In this city, the Arab geographer visited the sanctuary of Prophet Ŷirŷis: his tomb is on a corner of a mosque. Reference to a water source in Jonas hills is made "a mile away, more or less" (BATTUTA, 1356/1993, p.325). He continued by saying that the oral tradition ensured that the same prophet had commanded his people to be cleaned in it. Another spring is recorded in the present city of Nusaybin on the border of Turkey and Syria: "it is surrounded by a river that bends over it like a bracelet and born in one of the springs of a nearby hill." (BATTUTA, 1356/1993, p .326).

Finishing his descriptions of Iraq and Iran, Battuta dedicated the following pages of his Rihla to Yemen and East Africa, after his second pilgrimage. This period, from 1327 to 1330, is known as the maritime trips to East Africa and back to the Arabian Peninsula.

Nowadays, in the city of El-Quseir, in Egypt, one can visit a fort built in 1571 which has a small museum which hosts an example of the many boats used to cross the Red Sea towards Mecca. It is reasonable to say that the boats used by Battuta could be of the same type or even less developed than the one shown in figure 6 , since this dates back to the sixteenth century and Battuta's maritime travel was made in the fourteenth century.

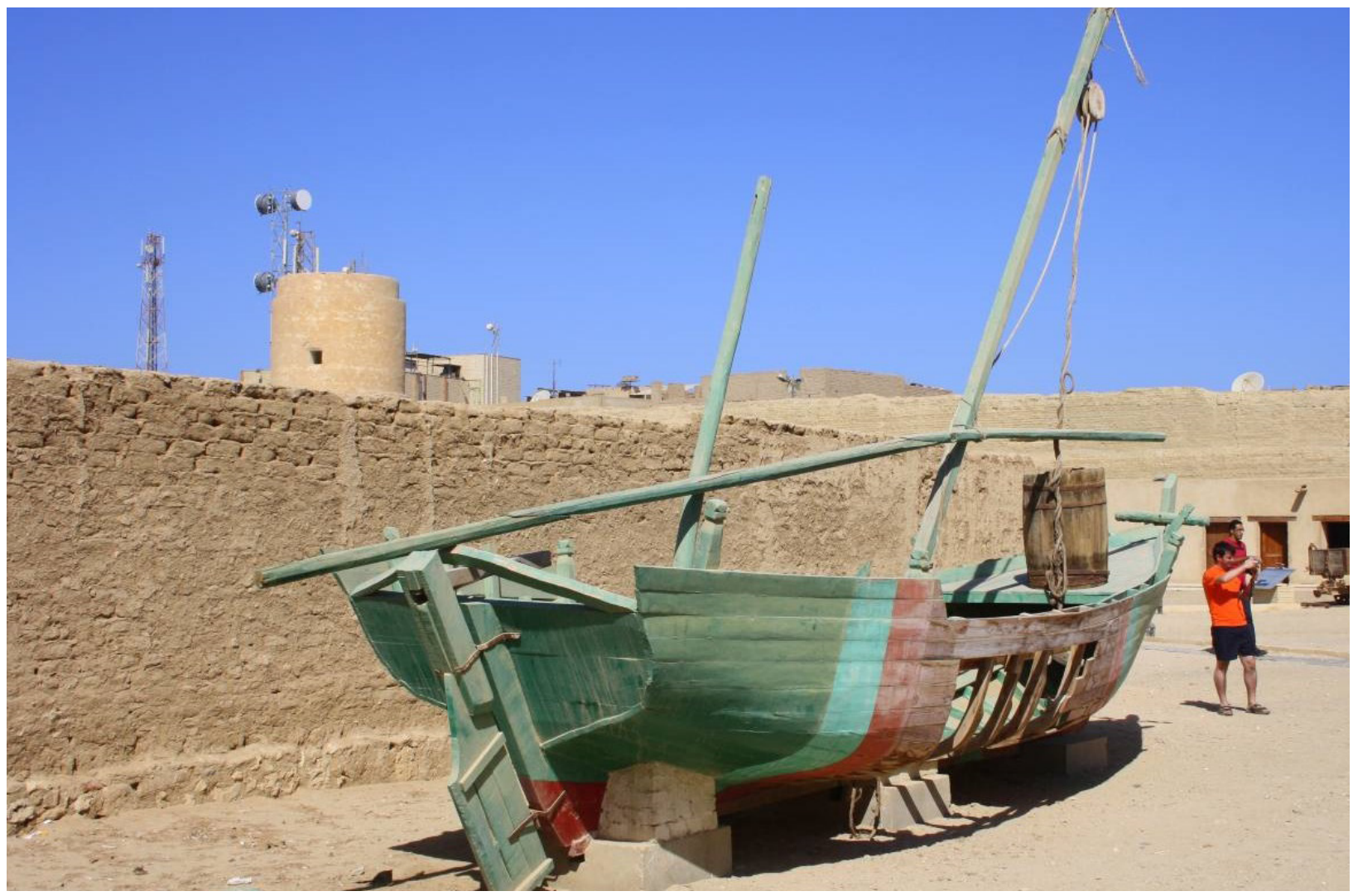

Figure 6 - Example of a vessel used by Muslims who went towards Mecca crossing the Red Sea (Photo: L.E.P.Travassos).

Leaving Mecca, Battuta went to Yemen. In Hadda, "built by the Persians", outside the city limits there are "some old cisterns and countless ponds to collect water, dug in hard rock next to 
each other." (BATTUTA, 1356/1993, p.334). Waltham (2004a) states that Yemen displays the same limestone of Saudi Arabia, more exposed in its mountainous terrain. The Jurassic limestone around Sana'a has several hot springs and some caves. The Tertiary limestone comprise the Wadi Hadramaut Plateau (to the east of the country), but information about its karst is still lacking.

From Yemen through the port of Aden (developed on undifferentiated Quaternary sediments), Battuta went by sea to Zayla (more likely to be the present-day Djibouti) and "after fifteen days of sailing", arrived to Mogadishu, an "extremely great city." (BATTUTA, 1356/1993, p .344). Brook (2004) affirms that the karst in Somalia develops mainly in the Haud Plateau and the country presents some karst springs. Battuta highlights nothing too significant in relation to the sacred underground in East Africa. His Mogadishu journey to Mombasa and later to Kilwa occurs by sea. Therefore, the traveler does not identify the small carbonate provinces of Ethiopia, Somalia, Kenya and Tanzania in his text. Schlüter (2008) points out that close to Mogadishu there is Jurassic limestone and along the coast south of the country, Mesozoic limestone.

Departuring from Kilwa (Tanzania), Battuta returned to Yemen by sea to Zafar, the "last village in Yemen in the coast of the Indian Ocean." (BATTUTA, 1356/1993, p.351). According to him, "from this port vessels departed towards Calicut", India "after twenty-eight days with good wind (...)" (BATTUTA, 1356/1993, p.351). In Zafar, the geographer devoted a few pages to the identification of the "Indian nuts" as the betel and coconut. He embarked in this city towards Oman and made some stops on his way. One of them was to visit Mount Lumcān, where he met with a "holy man" (BATTUTA, 1356/1993, p.358) who lived there. It was not possible to identify whether the mount described is developed in carbonates or non-carbonates. However, for the survival of the so-called "holy man", it would be required at least a small rock shelter and groundwater availability.

On his arrival in Muscat, the capital city of Oman, Battuta traveled to the city of Suhar by land through the desert. Cretaceous and Quaternary land served as the background until his departure from the port of Kalba in the direction of Hormuz, nowadays Iran. Waltham (2004a) states that Oman has the karst province of Dhofar, composed of the same Tertiary limestone of Yemen. However, it is distinguished by large collapsed dolines and underground systems down to 210 meters deep. The absence of records of this landscape in the work of Battuta happened because the most famous caves of Oman are located southwest of Muscat and others to the northwest of Suhar.

In Iran, Battuta probably encountered carbonate terrains, although this has not been recorded. According to Raeisi (2004), geologically speaking, Iran is part of the Alpine-Himalayan orogenic belt and the Zagros Mountains are possibly the most popular ones among karstologists and cavers in the world because it presents about $55 \%$ of the carbonate formations in the country. All in all, about $11 \%$ of the Iranian territory $(185.00 \mathrm{~km} 2)$ are karst developed in the Cretaceous and Tertiary carbonates (RAEISI, 2004). From Hormuz, Battuta headed overland towards Kawristan, to the port of Sīrāf, southeast of the country. From this location, Ibn Battuta began his third pilgrimage to Mecca.

Leaving Mecca once again, the traveler began what Abercrombe (1991, p.13) describes as "the long path to India through Anatolia and Central Asia". Towards Turkey, Battuta visits the sacred underground of Hebron and its surrounding areas again. In Latakia (Syria), he embarked on a Genoese sailboat and "after ten days with good wind" (BATTUTA, 1356/1993, p.375), he arrived in the region of Anatolia, in the coastal town of 'Alāyā. He visited Konia and went westward to Istanbul. Gunn and Günay (204) emphasize that the Turkish lands are mainly composed of limestone, dolomite and other carbonates which cover about $250,000 \mathrm{~km} 2$ of the country.

On considering the route Battuta described in his book, the carbonate karst was largely present on his journey though he does not mention this landscape specifically. The fact is that they are indirectly present in his Rihla when he describes many "baths" or the "abundance of water in the region", probable references to karst springs. Important sites like Pamukkale or Cappadocia were not mentioned, however. Battuta points out the city of Ephesus, but does not mention its hills and the Grotto of St. Paul. In Bursa, west of Istanbul, Battuta (1356/1993, p.399) underlined the sacred underground only in the form of a brief record of a fakir who lived in a small cave on a nearby hill. 
From Bursa, he moved on to Sinope and from this place he headed towards the east portion of Crimea via Black Sea to Karš (Kerch), a port city south of what today is Ukraine. From this city they went to Qirim, now Stary Krym. In this country, Vakhrushev and Dublyansky (2004) emphasize that the plains of the peninsula gradually rise towards the Crimean Mountains in the south. Its karst is well developed in the region and forms a continuous sequence of Jurassic limestone which is 50 to 1300 meters thick and more than $340 \mathrm{~km} 2$. From the point of view of karstology the region was first described in 1915 by Alexander Kruber, developing scientifically only in the 70s (VAKHRUSHEV; DUBLYANSKY, 2004).

On June 14th, 1334, Battuta started to describe his journey towards Constantinople, now Istanbul, Turkey, from a region he calls South of Russia. According to Gunn and Günay (2004), limestone, dolomite and other carbonate rocks cover about $1 / 3$ of the $250,000 \mathrm{~km} 2$ of the country. The best-known karst regions are the carbonates of the Taurus Mountains and the south-eastern lands of Anatolia (along the border with Syria), the Central Anatolia (south and west of Ankara) and along the Black Sea coast around Zonguldak and Thrace (west of Istanbul). For this reason, it would not be difficult to have descriptions of regional karst made by Battuta. However, in the 13 pages devoted to Constantinople, the only descriptions were of the city and its monasteries with no emphasis on caves or water sources.

Returning to Astrakhan, a city in southern Russia, Battuta sails for days on the river Volga. Then he headed towards Uzbekistan and Afghanistan by land, without mentioning karst features. He described only cities and mosques, not the karst of the Urals, for example. In Bukhara (Uzbekistan), he highlighted the tomb of "a wise imam Abu 'Abdallah al Bujari, Muslim Sheikh and author of a collection of traditions (...)" (BATTUTA, 1356/1993, p. 460). From this city, still in Uzbekistan, he departed to Samarkand, a city, considered one of the "biggest, most charming and splendid in the world" (BATTUTA, 1356/1993, p. 469). The traveler stressed the habits of the local population to perform pilgrimages to the tomb of a Muslim hero who had died in the conquest wars of the city. From Afghanistan towards Kabul, the Hindu Kusch called Battuta's attention because of its magnificent landscape. Nothing is recorded concerning the local karst, although Brooks and Gebauer (2004) claim that Afghanistan has significant carbonate karst areas. The region is known in the popular imagination as a maze of caves that housed insurgents for centuries against the various invasions of the territory.

The second part of Batutta's book is devoted to Sinde and India, the first being considered as the "Gate of Islam", one of the four provinces of Pakistan. According to Brooks and Gebauer (2004), the country is made up of limestone ranging from the Triassic to the Eocene ages. Leaving Sinde towards Delhi (India), he stated that it took about "50 days of march" (BATTUTA, 1356/1993, p. 487). Compared to its neighbouring countries, one can say that India has little karst. According to Brooks and Gebauer (2004), the exception is Meghalaya, to the northeast, with about $200 \mathrm{~km}$ of mapped caves. In relation to the sacred underground, the Kashmir Valley has many karst springs with temples built around them. The most famous troglodyte temple is the Cave of Amarnath. Every year, between May and July, near 25,000 pilgrims worship the god Shiva in it. Steward (2005), cited by Travassos (2010), reminds us that the Hindus worship an ice stalagmite which would be god Shiva. The other minor features are perceived as the gods Ganesha, Parvati and Bhairava.

It is worth mentioning that Battuta preferred to describe sacred caves or mountains related to the Islamic religion. Perhaps for this reason, the famous caves of Ellora, Elephanta and Ajanta do not appear in his Rihla when he traveled around India. According to Albanese, mentioned by Travassos (2010), caves and mountains have always been the high point of hierophanies in the Indian world. The former refer to Mother Earth and the latter, to Lord Shiva, who rises to the sky. The temples of Elephanta and Ellora date from the sixth to the eight centuries and represent the cave and the sacred mountain. The Ajanta Caves are located in the mountain range of the Western Ghat. The largest number of shrines and Buddhist monasteries of India are located along 1,600 km. 
The rock carvings began sometime between the second century B.C. and the second century A.D. Located about $100 \mathrm{~km}$ from Aurangabad, and carved in basalts, the site is one of the most famous places in the country.

Departing from Multam (Pakistan), the geographer returned to Dehli and, from this city, he moved in the direction of Daulatabad. The Devagiri Fort stands out in the landscape there but it was not mentioned by Battuta. He dedicated 156 pages of his work to India until the time he started to plan his journey to China but does not mention karst or any sacred sites, except for those tombs of Islamic "saints". He went from Sandapur to Honavar and Calicut and he departed from there to the Maldives in a Chinese junk. Battuta did not give any details about the continental shelf of the islands. He recorded just the vegetation, the reasons why people embraced Islam and the fact that Muslims are "religious and man of good manners." (BATTUTA, 1356/1993, p.662). Moving from the Maldives, he arrived in Ceylon (present-day Sri Lanka). The crystalline terrains on the island hold only 45 known caves that had been used as dwelling places in the past. Miocene limestone occurs in the far north and far south of the island (BROOKS; GEBAUER, 2004) but Battuta states simply that in "Kunakar (...) a virtuous man dug a cave at the foot of a mountain" (BATTUTA, 1356/1993, p. 688).

Further on in his text, Battuta (1356/1993, p. 689-690) described the Mountain of Sarandib, also known as "Adam's Peak". He described two paths that took the pilgrims to the mountain: the Father's Way and the Mother's Road. The former is used for climbing and is considered to be "hard and rough", different from the other path, which is easier and used for the faithful to descend. It is interesting to note that Battuta made references to the concepts of Geography of Religion which were underlined by Travassos (2010): mountains and sacred caves "share" the holiness in the perception of the pilgrims for whom sacrifice should be part of the activity of visiting a sacred place. Battuta (1356/1993) reported that there was a place in a cave (al-Khidr) where a karst spring with the same name started. He observed that pilgrims left all their belongings behind to start climbing for three kilometers to the summit of Adam's Peak.

After leaving Ceylon, the geographer went to Bengal and made records of the city of Chittagong. The limestone located north of Bangladesh and is not registered by Battuta. Emphasis is given to the mountains of Kamaru in Maghalaya (Assam). Battuta (1356/1993, p.704) states that these mountains can be seen from Chittagong, are about a month away and that they are vast and contiguous to China and Tibet. Here one can call attention to the fact that both regions have remarkable karst areas and caves. However, the main objective of Battuta was to find a holy man (Ŷalāl ad-Dīn at-Tabarīzī) who lived in these mountains. He did not mention any caves then.

Getting to the island of Sumatra, he did not speak much holy persons or caves. He dedicated the next pages to brief social descriptions and the vegetation on the island. Then, he traveled from Java to China, after "seventeen days with favorable wind, all sail and good crossing" (BATTUTA, $1356 / 1993$, p.720). Battuta is impressed with the size of the Chinese territory and the fact that it has "all kinds of products, fruits, cereals, gold and silver". He said "no other land could be compared to it" (BATTUTA, 1356/1993, p.720). A few pages were devoted to descriptions of famous Chinese ceramics, animals, the role of money to buy and sell items, the interest of the Chinese in art and the general conditions of Chinese as well. He characterized them as "pagans, idol worshipers who burn their dead as the Hindus" (BATTUTA, 1356/1993, p.721). Other considerations about Chinese customs were made up to the point where there was a record of a "very old elder (...) who inhabited a cave outside the city limits, which was dedicated to his devotions." (BATTUTA, 1356/1993, p. 728). The City of Sin Kalan is the Chinese city of Guangzhou in the present times.

Waltham (2004b) points out that China has a huge variety of karst that stretches over 500,000 $\mathrm{km} 2$. The provinces of Guangxi and Guizhou are the best known ones and the limestone ranges from the Devonian to the Triassic ages. Battuta does not describe any cave, differently from a famous 
Chinese traveller, the geographer Xu Xiake (1587-1641), who did this some centuries after the Arab traveler. From Guangzhou (Canton), Battuta went to Hangzhou (Hancheu), a city in the well-known karst region of South China, and from there to Beinjing. He described the Chinese capital city as "one of the largest metropolises in the world, but which does not follow the arrangement of other Chinese cities (...)" (BATTUTA, 1356/1993, p. 735). No mention to karst caves or tombs were made in the following pages.

Towards the end of his work, Battuta devoted several pages to his return and to his fourth pilgrimage. He mentioned the same countries of northern Africa, but opened up some new areas such as Andalusia and Mali. He wrote about Gibraltar, Granada and Malaga and although they are known by having a significant karst, there is no record of its phenomena then. The rock of Gibraltar or the "Silver Mountain" (Battuta, 1356/1993, p. 757) is described as the backdrop of battles between "the infidels" and the Muslims. It is known that the Rock of Gibraltar is composed of Mesozoic carbonates and there are numerous caves that were used for a long period in history. Finlayson and Rodríguez-Vidal (2004) state that about 140 caves and fissures have traces of human occupation since the period of the Neanderthals until now.

In the Empire of Mali, he would have visited the cities of Tumbuktu, Gao and Takedda and Assiou (in modern Algeria). Moret (2004) calls attention to the existence of cemetery-caves such as those used by the Dogon people in the cliffs of Bandiagara, south of Mali. Although ceremonial burials still occur in the region, they are disappearing due to the pressures exerted by Christianity and the westernization of traditional people. In his Rihla, Battuta did not mention these places.

\section{FINAL CONSIDERATIONS}

This research shows that the geography practiced by Muslim Arabs took into account the adaptation of people to the environment, the importance of natural resources (especially water) to survive in desert regions, the constructed environment and the conquest of territories. Moreover, it is believed that the fact that Muslims are instructed to perform the pilgrimage to Mecca at least once in their life makes travel a type of geographical exploration beyond going to that holy city which, along with trades, expanded the geographical horizon of Islam. Its geography - along with the access to the Hellenic, Mesopotamian, Iranian, Indian heritage as well as other conquests by Islam - was also of great importance for its development as an auxiliary of the government in the administration of the territories.

Even thought Staples (2009) claims that Battuta has used sections that were taken from the works of other travellers and that he tended to some exaggerations, his contributions to a new style within the travel literature genre, expanding the traditional descriptions of pilgrimages as well as including more personal information and a geographic coverage never seen before is undeniable. His work is a testimony to the rich diversity of the Medieval Islam of the fourteenth century by mixing mysticism, religious laws and customs.

Although there are no specific passages about the karst, the description of phenomena that occur more commonly in this type of landscape, e.g. caves and abundant sources of groundwater can be identified in Battuta's work. This probably occurs because the initial journey was almost exclusively motivated by religion. The descriptions of places are mostly made when Islam considered them sacred and theoretical insights on physical geography, for example, were not made.

Nevertheless, it is impossible to deny Ibn Battuta's techniques on geographical orientation as well as the contribution that their predecessors gave to the organization of the geographical knowledge available at that time. 


\section{BIBLIOGRAPHIC REFERENCE}

ABERCROMBIE, T. J. Ibn Batutta: Prince of travelers. National Geographic, v.180, n.3, p.02-39, December 1991.

A GRUTA. O Alcorão. Tradução de Mansour Challita. Rio de Janeiro: Associação Cultural Internacional Gibran, s.d. p. 150-157.

ALCORÃO. Português. Tradução de Mansour Challita. Rio de Janeiro: Associação Cultural Internacional Gibran, s.d.

AHMAD, S.M. A history of Arabic-Islamic Geography (9th-16th Century AD). Amman: Al Ahl-Bayt University, 1995.

ANDREYCHOUK, V; TRAVASSOS, L.E.P.; BARBOSA, E.P. As cavernas como objetos do turismo religioso em diferentes crenças religiosas: alguns exemplos mundiais. O Carste, v.22, n.2, p. 48-64, 2010.

BATTUTA, I. A través del Islam. Madrid: Alianza Editorial S.A., 1356/1993. Traduzido por Serafín Fanjul e Frederico Arbós.

BISSIO, B. O mundo falava árabe: a civilização árabe-islâmica através da obra de Ibn Khaldun e Ibn Battuta. Rio de Janeiro, Civilização Brasileira, 2012. 347 p.

BISSIO, B. A viagem e as suas narrativas no Islã medieval. Revista Litteris, v.4, p.1-18, março 2010.

BISSIO, B. Percepções do espaço no medievo islâmico (séc. XIV): o exemplo de Ibn Khaldun e Ibn Battuta. 2008. 417f. Tese (Doutorado). Programa de Pós-Graduação em História, Universidade Federal Fluminense.

BROOK, G. A. Africa, Sub-Saharan. In: GUNN, John (ed.). Encyclopedia of Caves and Karst Science. New York/London: Fitzroy Dearborn, 2004. p. 41-48

BROOKS, S.; GEBAUER, D. Indian Subcontinent. In: GUNN, John (ed.). Encyclopedia of Caves and Karst Science. New York/London: Fitzroy Dearborn, 2004. p. 953-962.

BURLOT, Joseph. A Civilização Islâmica. Mem Martins, P. E. A., 1992, 304 p.

BUSH-JOSEPH, K.. Ibn Jubayr: The Rihla. Senior Honors Seminar in History. Georgetown University. Disponível em : $<$ http://repository.library.georgetown. edu/bitstream/handle/10822/557913/Bush-JosephThesis. pdf? sequence=1> Acesso em 09 Out 2013.

CHALLITA, M. O que você deve saber para aproveitar plenamente a leitura do Alcorão. In: O Alcorão. Tradução de Mansour Challita. Rio de Janeiro: Associação Cultural Internacional Gibran, s.d. p. XVII-XXX CLAVAL, P. Histoire de la Géographie. Paris: P.U.F, 1995. 127 p.

DEFRÉMERY, C.; SANGUINETTI, B.R. Voyages d'Ibn Batoutah. Paris: Société Asiatic, 1853-1858. 4 vols. (Arabic and French text).

DUCKECK, J. The Caves of Hercules - Cave of Africa. In: DUCKECK, J. Show Caves.com, 2011. Disponível em: <http://www.showcaves.com/english/misc/showcaves/Hercules.html> Acesso em: 05 mai 2011.

DU MESNIL, E. T. Le Livre et la Carte. Représentations de l'Afrique par Bakri (Xie siècle) et Idrisi (XIIe siècle). CNC, Paris, n. 210, Décembre, p.53-61, 2011.

FANJUL, S.; ARBÓS, F. Introducción. In: BATTUTA, I. A través del Islam. Madrid: Alianza Editorial S.A., 1993. p.23-92

FINLAYSON, C.; RODRÍGUEZ-VIDAL, J. GIBRALTAR CAVES, GIBRALTAR: ARCHAEOLOGY. In: GUNN, John (ed.). Encyclopedia of Caves and Karst Science. New York/London: Fitzroy Dearborn, 2004. p. 794-798.

GEOLOGICAL SURVEY. Jericho - Israel grid. Israel: Geological Survey, 1972. 1 mapa: color. Escala: 1:50.000.

GEOLOGICAL SURVEY OF PAKISTAN. Rawalpindi: Geological Survey, 1964. 1 mapa: color. Escala: $1: 2.000 .000$.

GILLIOT, C. Libraries. In: MERI, J.W. (Ed.). Medieval Islamic Civilization: an encyclopedia. New York: Routledge, 2006. p. 450-453. 
GREIFFITH, S. Christian lore and the Arabic Qur'an: The "Companions of the Cave" in Surat al-Kahf and in Syriac Christian tradition. In: REYNOLDS, Gabriel Said (ed.). The Qur'an in its historical context. USA/CANADA: Routledge, 2008. p. 109-137.

GUNN, J.; GÜNAY, G. Turkey. In: GUNN, John (ed.). Encyclopedia of Caves and Karst Science. New York/London: Fitzroy Dearborn, 2004. p. 1583-1589.

HOLT-JENSEN, A. Geography: history and concepts. 4.ed. London: SAGE, 2009.

MINISTRY OF PETROLEUM AND MINERAL RESOURCES. Geological map of Syria. Damascus: General Establishment of Surveying, 1986. 1 mapa: color. Escala: 1:1.000.000

MINISTRY OF OIL AND MINERALS / PETROLEUM EXPLORATION AND PRODUCTION AUTHORITY. Geological map of Yemen. Ministry of Oil and Minerals/Petroleum Exploration and Production Authority, 2004. 1 mapa: color. Escala: 1:1.000.000

MOHAMMED, M. R. Al-Rihla and curriculum theory: a qualitative comparative study of contemporary and historical muslim travelers in search of knowledge. 260f. (Tese de Doutorado). Texas A \& M University, 2011.

MOURET, C. Burials in caves. In: GUNN, John (ed.). Encyclopedia of Caves and Karst Science. New York/London: Fitzroy Dearborn, 2004. p. 345-349.

O ALCORÃO SAGRADO. Foz do Iguaçu: Centro Cultural Beneficente Islâmico de Foz do Iguaçu. Disponível em: < http://www.islam.com.br/quoran/index.htm> Acesso em 03 mai 2011.

PERRITAZ, L. North, Africa. In: GUNN, John (ed.). Encyclopedia of Caves and Karst Science. New York/London: Fitzroy Dearborn, 2004. p. 26-33.

RAEISI, E. Iran. In: GUNN, John (ed.). Encyclopedia of Caves and Karst Science. New York/London: Fitzroy Dearborn, 2004. p. 992-995

RECLUS, E. The universal geography: earth and its inhabitants. Edited and translated by A. H. Keane, B.A. Memb. of Council, Anthrop. Institute; Cor. Memb. Italian Anthrop. Soc.; Professor of Hindustani, University Col. London; Author of “Asia”, Etc. London: J.S. Virtue \& Co. Limited, 1876-1894. v.11 (North-West Africa).

SAUDI Geological Survey. Zamzam Studies and Research Centre, 2010. Disponível em: <http://www.sgs. org.sa/English/earth/Pages/Zamzam.aspx> Acesso em: 10 mai 2011.

SERVICE GEOLOGIQUE DU MAROC. Carte Structurale du Maroc. Marrakech: Ministre de L'energie et des Mines, 1982. 1 mapa: color. Escala: 1:2.000.000

SCHLÜTER, T. Geological Atlas of Africa: with notes on stratigraphy, tectonics, economic geology, geohazards, geosites and geoscientific education of each country. 2.ed. Berlim: Springer, 2008. 307p.

STAPLES, E. Ibn Battuta, Abu Abd Allah Muhammad al-Lawati (1303-1377). In: CAMPO, J.E. (Ed.). Encyclopedia of Islam. New York: Facts On File, Inc., 2009. p.330-330.

STEWARD, P.J. Myth and legends, caves in. In: CULVER, D.C.; WHITE, W.B (Ed.). Encyclopedia of Caves. USA: ElsevierAcademic Prress, 2005. p.406-408.

THE EGYPTIAN GEOLOGICAL SURVEY. Geological map of Egypt. Cairo: The Egyptian Geological Survey and Mining Authority, 1981. 1 mapa: color. Escala: 1:2.000.000

THE HOLY QUR'AN. Eletronic electronic version translated by M.H. Shakir and published by Tahrike Tarsile Qur'an, Inc., 1983. Disponível em: < http://quod.lib.umich.edu/k/koran/> Acesso em 03 mai 2011. TRAVASSOS, L.E.P. Ibn Battuta e os subterrâneos sagrados do Islã. In: $32^{\circ}$ Congresso Brasileiro de Espeleologia, 2013, Barreiras-BA. Anais... Campinas: SBE, 2013. p.207-213.

TRAVASSOS, L.E.P. A importância cultural do carste e das cavernas. 2010. 372f. Tese (Doutorado). Programa de Pós-Graduação em Geografia, Pontifícia Universidade Católica de Minas Gerais.

TOLMACHEVA, M.A. Idrisi. In: MERI, J.W. (Ed.). Medieval Islamic Civilization: an encyclopedia. New York: Routledge, 2006a. p. 379-381.

WAINES, D. The Odyssey of Ibn Battuta: uncommon tales of Medieval Adventurer. Chicago: the University of Chicago Press, 2010.

WALTHAM, T. Asia, Southwest. In: GUNN, John (ed.). Encyclopedia of Caves and Karst Science. New York/London: Fitzroy Dearborn, 2004a. p. 238-242. 
WALTHAM, T. China. In: GUNN, John (ed.). Encyclopedia of Caves and Karst Science. New York/ London: Fitzroy Dearborn, 2004b. p. 444-451.

WALLEY, C.D. The Geological Map of Lebanon: a summary. American University of Beirut. Disponível em: < http://ddc.aub.edu.lb/projects/geology/geology-of-lebanon/> Acesso em 12 mai 2011.

VAKHRUSHEV, B.; DUBLYANSKY, V. Crimea, Ukraine. In: GUNN, John (ed.). Encyclopedia of Caves and Karst Science. New York/London: Fitzroy Dearborn, 2004. p. 518-521.

Submitted february 2016

Accepted april 2016 